\title{
Lagomorphs from the Miocene of Sandelzhausen (southern Germany)
}

\author{
Chiara Angelone
}

Received: 2 January 2008/ Accepted: 29 August 2008/Published online: 3 February 2009

(C) Springer-Verlag 2009

\begin{abstract}
Three genera of lagomorphs, Prolagus, Lagopsis, and "Amphilagus," were identified during a revision of the lagomorph material from Sandelzhausen (MN5, Early/Middle Miocene boundary, southern Germany). Evidence of two morphological and dimensional classes were observed at some tooth positions in Prolagus (some p3 show an unmistakable P. oeningensis morphology, others closely resemble $P$. crusafonti), but not at other tooth positions (e.g., M1-2). Insufficient data from Sandelzhausen precludes identification of two different species of Prolagus from this locality, and to define the characteristics of the possible $P$. crusafonti-like species. Thus, all Prolagus specimens have been classified as $P$. aff. oeningensis. The genus Lagopsis is represented by L. cf. penai, whose presence is compatible with a MN5 age. The relative abundance of Lagopsis to Prolagus may indicate relatively cool and wet palaeoclimatic conditions. The largest primitive lagomorph species from continental Europe is present at Sandelzhausen. Morphological and dimensional comparisons with other European primitive lagomorphs exclude any affinity with the genera Eurolagus and Titanomys and with the species included in "Amphilagus ulmensis". Some common features with "Amphilagus antiquus" were observed, although they are not sufficient for the attribution to this taxon. Until there is a general revision of European primitive lagomorphs, the Sandelzhausen giant lagomorph is classified as "Amphilagus" sp.
\end{abstract}

C. Angelone $(\square)$

Dipartimento di Scienze Geologiche, Università Roma Tre,

Largo San Leonardo Murialdo 1, 00146 Rome, Italy

e-mail: angelone@uniroma3.it

C. Angelone

Dipartimento di Scienze della Terra, Università di Torino, via Valperga Caluso 35, 10125 Turin, Italy
Its origins, whether from evolution within Europe or migration from Asia, remain unknown.

Keywords Prolagus - Lagopsis . "Amphilagus" . Boundary Early/Middle Miocene · Southern Germany

Kurzfassung Die Revision des Lagomorphen-Materials von Sandelzhausen (MN5, Grenze Unter-/Mittelmiozän, Süddeutschland) ermöglichte die Identifizierung von Vertretern dreier Gattungen: Prolagus, Lagopsis and "Amphilagus." Prolagus ist repräsentiert durch einige P/3, die zwei morpho-metrische Klassen repräsentieren, die einesteils mit $P$. oeningensis übereinstimmen und anderenteils $P$. crusafonti ähnlich sind. Doch Zähne anderer Positionen zeigen diese Gruppierung nicht. Damit sind die zur Verfügung stehenden Daten nicht ausreichend um einerseits zwei verschiedene Prolagus-Arten und andererseits charakterisierende Merkmale einer $P$. crusafonti-ähnlichen Art in Sandelzhausen zu belegen. Deshalb wurde das gesamte Prolagus-Material als $P$. aff. oeningensis eingestuft. Die Gattung Lagopsis ist durch $L$. cf. penai vertreten, was die Datierung der Fundstelle als MN5 unterstützt. Die größere Häufigkeit von Prolagus im Verhältnis zu Lagopsis könnte relativ kühle und feuchte paläoklimatische Bedingungen anzeigen. Darüber hinaus enthält die LagomorphenFauna von Sandelzhausen die größte, primitive Hasen-Art Mitteleuropas. Morphologische und metrische Vergleiche mit anderen primitiven Lagomorpha Europas erlauben jede verwandschaftliche Beziehung zu den Gattungen Eurolagus und Titanomys sowie zu den unter "Amphilagus ulmensis" zusammengefassten Arten auszuschliessen. Obwohl einige gemeinsame Merkmale mit "Amphilagus antiquus" vorhanden sind, sind sie nicht ausreichend um sie dort einzuordnen. Bis zu einer Revision aller primitiven Lagomorpha Europas wird der besonders große, primitive 
Lagomorphe von Sandelzhausen als "Amphilagus" sp. klassifiziert und seine Herkunft (lokale europäische Evolution oder Migration aus Asien) bleibt unbekannt.

Schlüsselwörter Prolagus · Lagopsis . "Amphilagus" . Grenze Unter-/Mittelmiozän · Süddeutschland

\section{Introduction}

The Sandelzhausen fossil site (early middle MN5, Early/ Middle Miocene, southern Germany) is an exceptionally rich locality of the Molasse Basin. The sediments of the fossil site, deposited successively in temporary ponds and a perennial lake, are part of the latest infillings of the basin (Upper Freshwater Molasse). These sediments were deposited in a palaeoenvironment characterized by a mosaic of wetlands, as testified by the sedimentological and faunal records (Moser et al. 2009 this volume and references therein).

The aim of this paper is to analyze the lagomorph component of the Sandelzhausen fossil site. Preliminary data about the subject were provided by Fahlbusch et al. (1974), but further investigation was needed in light of the general systematic revisions of fossil lagomorphs of western and southern Europe (López Martínez 1974, 1989; Angelone 2005) and their biochronological and palaeogeographical implications.

\section{Materials and methods}

The fossil material, collected along a section of about $3.5 \mathrm{~m}$ (Moser et al. 2009 this volume), was extracted from several different horizons, but has been analyzed in its entirety, except for Fig. 2 in which only the sample from Violette Lage (Moser et al. 2009 this volume) has been taken into consideration for practical reasons. Actually, detailed studies have demonstrated that the differences in size and relative abundances of faunal elements along the section are due to taphonomical reasons, namely the decantation of material along a water column (Moser et al. 2009 this volume and references therein). This may also explain the decrease in size of the lagomorph teeth towards the top of the section.

All the available lagomorph remains from Sandelzhausen, curated at the Bayerische Staatsammlung für Paläontologie und historische Geologie (Munich), have been revised. Except for the worst preserved specimens, for the incisors and the lower molariforms of Prolagus and Lagopsis, most of the revised items have been classified and inventoried (under the inventory number prefix BSPG 1959 II, what is omitted in the following text).
The occlusal surface of each tooth was drawn using a camera lucida mounted on a Leica MS5 binocular microscope. Occlusal measurements were taken from the drawings. The nomenclature follows López Martínez (1989) and Angelone and Sesé (2009). The measurements introduced for the genus Prolagus by Angelone and Sesé (2009) are used in this paper and adapted also (when possible) to M1-2 of Prolagus and to Lagopsis; the measurements of “Amphilagus” follow López Martínez (1989).

Systematic palaeontology

Order Lagomorpha Brandt, 1855

Family Ochotonidae Thomas, 1897

Genus Prolagus Pomel, 1853

Prolagus aff. oeningensis (König, 1825)

Fig. 1a-k, Table 1

Material

p3 sin: 15001, 15004, 15016-15017, 15030, 15056, 15072-15075, 15094-15100, 15125-15126, 15156-15157, 15186, 15194-15196, 15209-15212, 15231, 15234, 15249, 15266-15267, 15278, 15321, 15326, 15337-15340, 15343, 15366, 15392, 15401, 15421-15426, 15428-15430, 15441-15449, 15461-15467, 15471-15472; p3 dx: 15002-15003, 15015, 15048-15049, 15051-15052, 15057, 15064, 15071, 15076, 15089-15093, 15127, 15151, 15158, 15167-15168, 15175-15176, 15185, 15191-15193, 15213, $15228,15248,15261,15268,15279,15302,15320$, 15341-15342, 15344-15345, 15360, 15367, 15408-15409, 15431-15440, 15450-15460, 15470; d3 sin: 15014, 15147, 15159, 15303, 15386, 15629-15632, 15634-15637; d3 dx: 15082, 15103, 15281-15282, 15382, 15621-15622, 15624-15627, 15904; d4 sin: 15169, 15283, 15283bis, 15382bis, 15378, 15393, 15638-15639; d4 dx: 15143; P2 sin: $15005,15019,15031,15045,15050,15061,15077$, ?15080, 15106-15107, 15129, 15142, 15170, 15197, ?15215, 15216, 15236, 15250, ?15253, 15262, 15269, 15327, 15361, 15387, 15394, 15602-15611; P2 dx: 15040, 15078-15079, 15081, 15104-15105, 15128, 15152, 15177, ?15178, 15198, ?15200, 15246, 15286, ?15328, 1534615347, 15399, 15594-15601; P3 sin: 15006-15007, 15054, $15068,15085,15108,15112,15131,15153,15160$, 15179-15180, 15187-15188, 15201-15202, 15217, 15220, 15238, 15251-15252, 15259, 15289-15290, 15312-15313, 15316, 15330-15331, 15362-15363, 15368-15371, 15388-15389, 15395, 15406, 15411-15412, 15477-15478, 15481, 15494-15495, 15498-15501, 15503, 15520-15521; P3 dx: 15041-15042, 15046, 15053, 15083-15084, 15109-15111, 15132-15135, 15144-15145, 15208, 15218-15219, 15237, 15239, 15254-15255, 15271-15273, 15287-15288, 15304, 15322-15324, 15329, 15348-15349, 


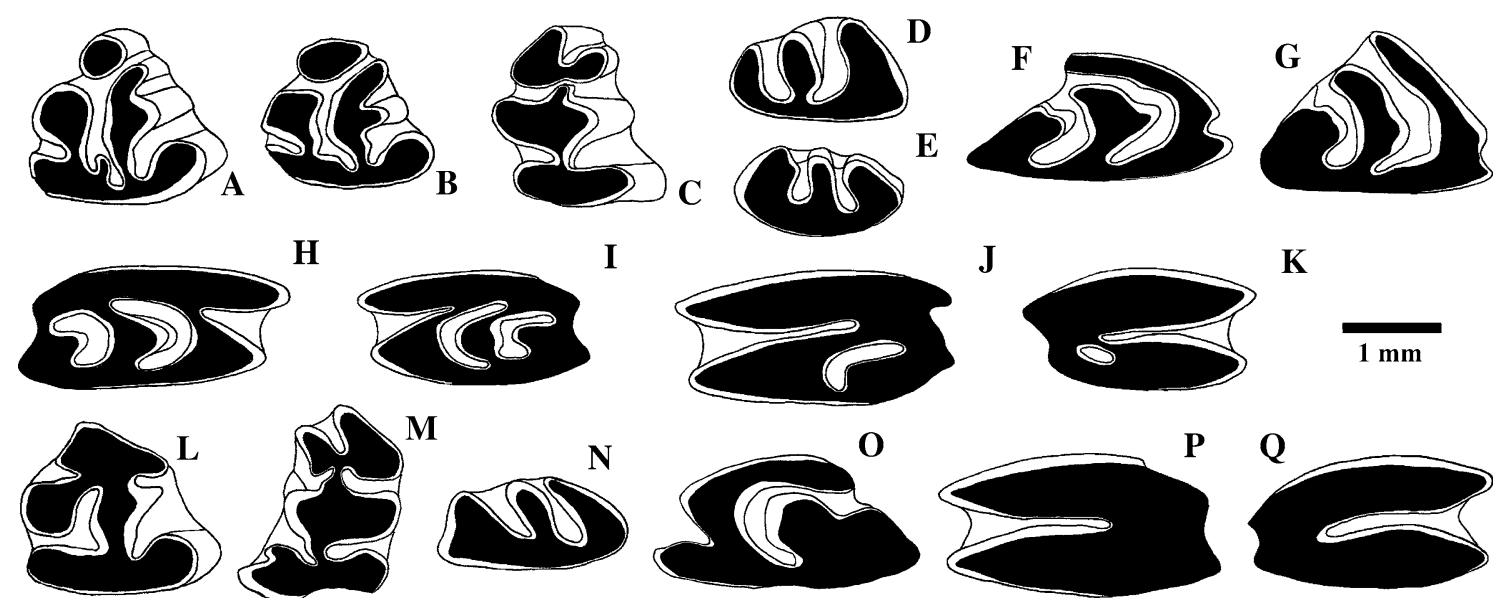

Fig. 1 Prolagus aff. oeningensis: a, b right p3 15.439 and 15.435; c right d3 15.621; d, e right and left P2 15.599 and 15.606; f, g right P3 15.512 and $15.510 ; \mathbf{h}, \mathbf{i}$ right and left P4 15.524 and 15.538; $\mathbf{j}$ left M1

15351-15352, 15405, 15410, 15483-15489, 15504, 15507-15508, 15510, 15512-15513, 15515, 15517-15519; P4 sin: 15022, 15034, 15044, 15055, 15058, 15062, 15065, $15113-15115,15137,15162,15171-15172,15203$, 15221-15222, 15240, 15242, 15247, 15263-15264, 15274, 15291-15293, 15296, 15305, 15325, 15333, 15364, 15379, 15535-15547, 15549; P4 dx: 15059, 15069-15070, 15086-15088, 15136, 15223-15224, 15229, 15241, 15294-15295, 15332, 15372, 15383, 15396, 15400, 15402, 15404, 15413-15414, 1552215529; M1 sin: 15011, 15024, $15035,15117,15120,15150,15155,15163-15164,15173$, 15181-15183, 15206, 15256, 15275, 15311, 15317-15318, 15353-15354, 15555-15569; M1 dx: 15009-15010, 15023, 15027, 15029, 15036-15037, 15039, 15116, 15118-15119, ?15146, 15149, 15154, 15189, 15204, $15225,15260,15276,15297-15298,15310,15334,15355$, 15373, 15384-15385, 15390, 15398, 15415, 15550-15554; M2 sin: 15025, 15060, 15124, 15138-15139, 15166, 15184, 15190, 15232, ?15233, 15243-15244, 15257, 15335-15336, 15365, ?15377, 15380, 15397, 15407; M2 dx: 15012-15013, 15043, 15063, 15067, 15121-15123, 15140-15141, 15165, 15205, 15207, 15227, 15230, 15245, 15258, 15277, 15300-15301, 15315, 15319, 15381, 15391, 15403, 15570-15577; D2 sin: 15284; D3/4 sin: 15285, 15314, 15374-15375, ?15376, 15640-15643; D3/4 dx: 15047, ?15306, 15307, 15644.

\section{Description}

D2: slender hypercone, lagicone, and postcone; the lingual part of the only available specimen is broken; deep, almost straight mesoflexus; paraflexus very deep and curved.

D3-4: globular centrocone; bilobed postcone; enamel present on labial side.
15.560; k right M2 15.572. Lagopsis cf. penai: I right p3 15.785; m left d3 15.713; n left P2 15.701; o left P3 15.714; p left P4/M1 15.775; q right M2 15.712

P2: most specimens have a well-developed hypercone even if the stage of an incipient mesial hyperloph is not reached; lagicone straight, wide, and slightly shorter than the hypercone; postcone often reduced in width and shorter than lagicone and hypercone; in most specimens para- and mesoflexus are wide and deep as in typical $P$. oeningensis, while in a minority of specimens the paraflexid is shorter, as in $P$. crusafonti.

P3: precone with frequent enamel hiatus; mesial hyperloph inclination and length extremely variable, as well as hypoflexus depth and mesial versus distal hypercone protrusion; the postcone may be indented anteriorly; the centrocone may not reach the edge of the tooth, and its proportions and type of connection with respect to the lagicone are quite variable.

P4: hypoflexus depth from $1 / 3$ to $1 / 2$ of the tooth "partial width" (AA in Angelone and Sesé 2009), V-shaped or with parallel sides on its labial part and divergent sides on the lingual part; mesial hyperloph length $55-70 \%$ of total length; C-shaped para- and metafossettes, both quite variable in size; a small, round accessory cusp may be present above the mesofossette.

M1-2: hypoflexus moderately deep (2/3-3/4 of AA), with the same shape as in $\mathrm{P} 4$; the fossettes are present in both M1 and M2, but are J-shaped in M1 and usually round or oval in M2; an accessory, round mesofossette may be present in M1 above the parafossette.

d3: in about $20 \%$ of individuals a small, round hypoconulid, separated from the talonid, is present, but fused to the talonid in later stages of wear; these specimens show a flattened anteroconid, a very deep centroflexid and a trigonid separate from the talonid. In specimens without a hypoconulid, the anteroconid is always indented by a very 


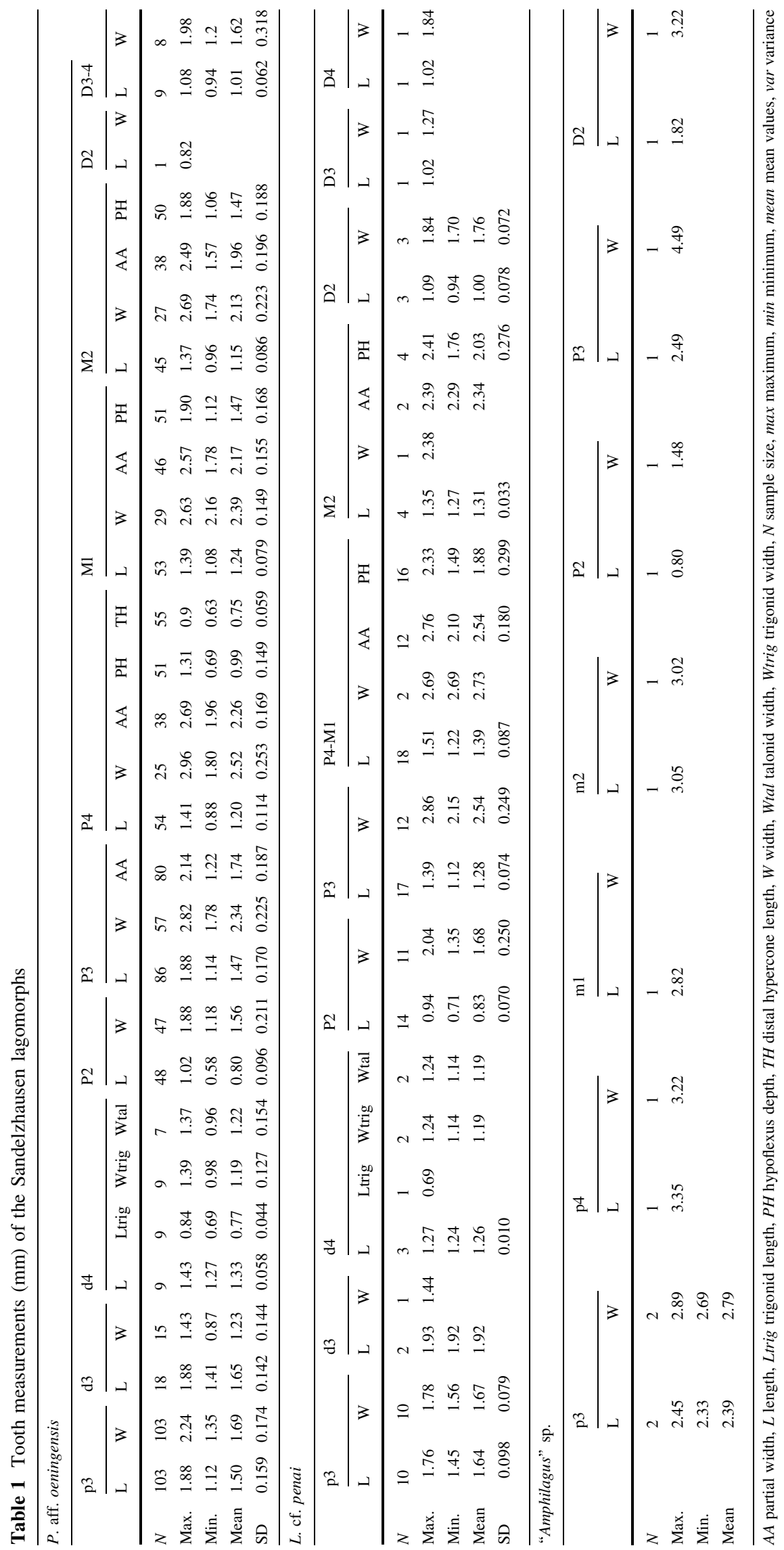


deep anteroflexid and almost always separated from the trigonid (as in P. oeningensis); the centroflexid depth and the protoconulid development are extremely variable; the centroisthmus is almost always present; in about $25 \%$ of specimens without a hypoconulid a small labial cusp is present at the base of the tooth between the trigonid and talonid, and in about $50 \%$ of cases an anterior protrusion is present on the lingual part of the entoconid.

d4: labially indented trigonid with usually distinct anterior lobe $(75 \%)$, but usually with a feeble paraflexid. One specimen (out of eight) has a deep paraflexid and a centroflexid.

p3: two morphotypes have been observed; one of them shows the typical $P$. oeningensis traits: round anteroconid, which is smaller than the metaconid, short and straight mesoflexus, well-developed crochet, and elongated shape; the other shows $P$. crusafonti characteristics: oval anteroconid as large as the metaconid, deep and curved mesoflexus, reduced crochet, overall shapeless elongated, and usually also smaller in size.

Analysis of the Prolagus specimens from Sandelzhausen demonstrates the presence, in some teeth, of two morphotypes, often corresponding to two different size classes. This is the case of $\mathrm{p} 3$, in which the larger elements (Fig. 1a, SDZH1 in Fig. 2c) have the unmistakable morphology of $P$. oeningensis (MN4-MN8; Fig. 2a), while the other ones (Fig. 1b, SDZH2 in Fig. 2c) closely resemble P. crusafonti (MN9-MN12; Fig. 2b). Two morphological classes can be observed also in P2 and d3. In P2 their characteristics correspond roughly to $P$. oeningensis and $P$. crusafonti (even if the differences between them are not as distinct as in p3; Figs. 1d, e). In d3 one of the two morphotypes resembles $P$. oeningensis; the other morphotype does not show the advanced characteristics of $P$. crusafonti, and is even more primitive than the $\mathrm{d} 3$ of $P$. oeningensis. The morphology of $\mathrm{P} 3$ is extremely variable: so much so that the material cannot be divided into different morphological classes. In P4 the range of morphological variability is rather continuous, while in M1-2 no differences in the dental pattern were observed.

These observations suggest the probable presence in Sandelzhausen of two species of Prolagus. However, the available evidence is not sufficient to differentiate them with all the necessary systematic details. For this reason it is preferable to group all the Prolagus remains from Sandelzhausen under Prolagus aff. oeningensis. A general revision of German Early/Middle Miocene Prolagus material would verify the existence of a $P$. crusafonti-like species sympatric with $P$. oeningensis, and would clarify its temporal and spatial distribution, and its relationship with P. crusafonti. Prolagus crusafonti is believed to have originated in western Europe and to have replaced P. oeningensis after MN9 (López Martínez 1989). Thus, the resemblance of some Prolagus remains from Sandelzhausen with $P$. crusafonti may be due to convergency or $P$. crusafonti may have appeared in central Europe during MN5 and did not spread in western and eastern Europe before MN9.

Genus Lagopsis Schlosser, 1884

Lagopsis cf. penai (Royo, 1928)

Figs. 11-q, Table 1

\section{Material}

p3 sin: 15719, ?15753, 15767, 15771, 15784, 15786; p3 dx: 15704, 15720, 15741, 15762, 15765, 15770, 15778, 15785; d3 sin: 15713, 15728, 15798 (ex15633); d3 dx: 15018, 15623, 15628, 15738, 15763; d4 sin: ?15214, 15710; P2 sin: 15701, ?15721, ?15759, 15766, 1576815769, 15774, 15781-?15782, ?15795, ?15796; P2 dx: 15702, 15708, 15742, 15751, 15794, 15797; P3 sin: 15714, 15723, 15727, 15729-15731, 15748, 15760, 15732-15733, 15775, 15779, 15783, 15790; P3 dx: 15703, 15722, 15735,

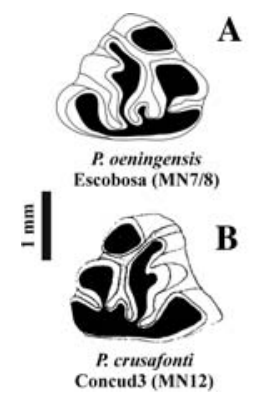

Fig. 2 a, b Occlusal surface morphology of $\mathrm{p} 3$ of $P$. oeningensis and $P$. crusafonti; c p3 length $(L) /$ width $(W)$ scatterplot comparing $P$. oeningensis $(O E)$ from Escobosa de Calatañazor (data from Angelone and Sesé 2009), P. crusafonti (CRU) from Hostalets superior, Viladecabals, El Lugarejo, Los Aljezares (combined data

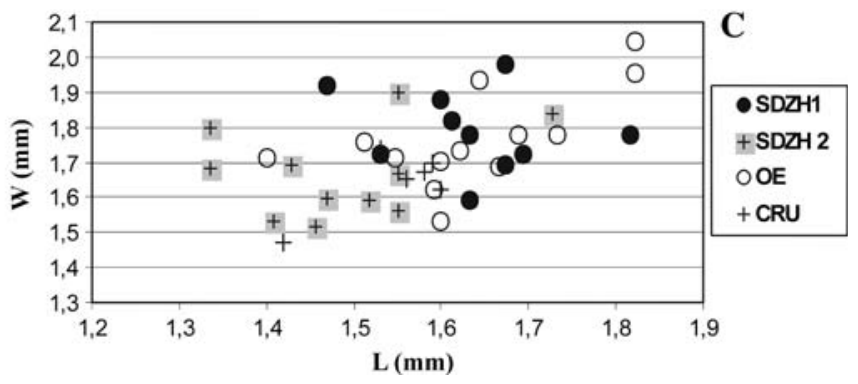

from López Martínez 1989) and P. aff. oeningensis from Sandelzhausen. $P$. aff. oeningensis (sample from "Violette Lage," see Moser et al. 2009 this volume) has been divided into two parts: SDZH1, corresponding to the P. oeningensis morphotype, and SDZH2, corresponding to the P. crusafonti-like morphotype 
15743, 15746, 15787-15789; P4/M1 sin: 15705, 15709, 15716-15718, 15733, 15736, 15744, 15747, 15761, 15793; P4/M1 dx: 15711, 15715, ?15745, 15750, 15755, 15764, 15777; M2 sin: 15749, 15752, 15775; M2 dx: 15712, 15725, ?15726, 15737; D2 sin: 15724, 15791; D2 dx: 15754, 15757; D3 sin: 15739; D3 dx:15732, 15792; D4 dx: 15756, 15758, 15799 (ex 15645).

\section{Description}

D2: mesial hyperloph and hypoflexus poorly developed; deep para- and mesoflexus; postcone indented in less worn individuals.

D3: long paraflexid reaching the tooth distal part; mesofossette present; deep, V-shaped hypoflexus.

D4: very deep hypoflexus; mesial hypercone approximately as long as the distal one; long parafossette, enlarged in its mesial side; lozenge-shaped mesofossette.

P2: hypercone indented; postcone long and relatively wide.

P3: mesial hyperloph covering lagicone and mesoflexus; distal hypercone relatively short; deep hypoflexus.

P4-M2: molariform teeth; hypoflexus depth not exceeding $2 / 3$ or $3 / 4$ of tooth width.

d3: deep, V-shaped anteroflexid; anteroconid connected to meta- and protoconid $(50 \%)$ even in early stages of wear; indented hypocone.

d4: trapezoidal trigonid, not indented labially as in Prolagus, connected to the triangular, talonid slightly indented lingually by a thin, central isthmus. p3: triangular anteroconid with incipient anteroflexid (cement in about $10 \%$ of cases); anteroconid larger than the quadrangular metaconid and L-shaped mesoflexid; thin protoconid; entoconid hiatus may be present.

The following dental characters of Lagopsis from Sandelzhausen were used to classify it as L. cf. penai (see Fig. 3 for comparison with L. penai, L. cf. verus, L. verus and other populations attributed to $L$. cf. penai):

- p3 with distinct, triangular anteroconid and incipient anteroflexid

- P2 with slightly indented precone, postcone longer than in $L$. penai, but not as reduced in width as in L. verus

- P3 with mesial hyperloph covering lagicone, deep hypoflexus, shallow mesoflexus

- molariform P4 with hypoflexus depth not exceeding 2/3 or $3 / 4$ of tooth width

The dimensions of Lagopsis from Sandelzhausen are in the range of L. cf. penai (Fig. 4).

Lagopsis is a good biochronological marker: four Lagopsis biozones, corresponding to four evolutionary stages of the Lagopsis lineage, have been recognized in the Iberian Peninsula and in western central Europe (López Martínez 1989). Lagopsis cf. penai characterizes MN4b + MN5. The presence of L. cf. penai at Sandelzhausen (MN5) suggests that this biozonation is applicable to the rest of central Europe.

The genus Lagopsis also has palaeoclimatic value, if coupled with the genus Prolagus. Lagopsis is supposed to have been better adapted to warmer temperatures and more arid conditions than Prolagus (López Martínez 1977, 1984, 2001). Thus, in the case of Sandelzhausen, where the
Fig. 3 Examples of dental morphologies of different populations of genus Lagopsis. a-c Villafeliche 2; d Navarrete; e-g Rubí Papiol; h Rubielos de Mora; i-k Armantes 7; l-o La Grive (from López Martínez, 1989)

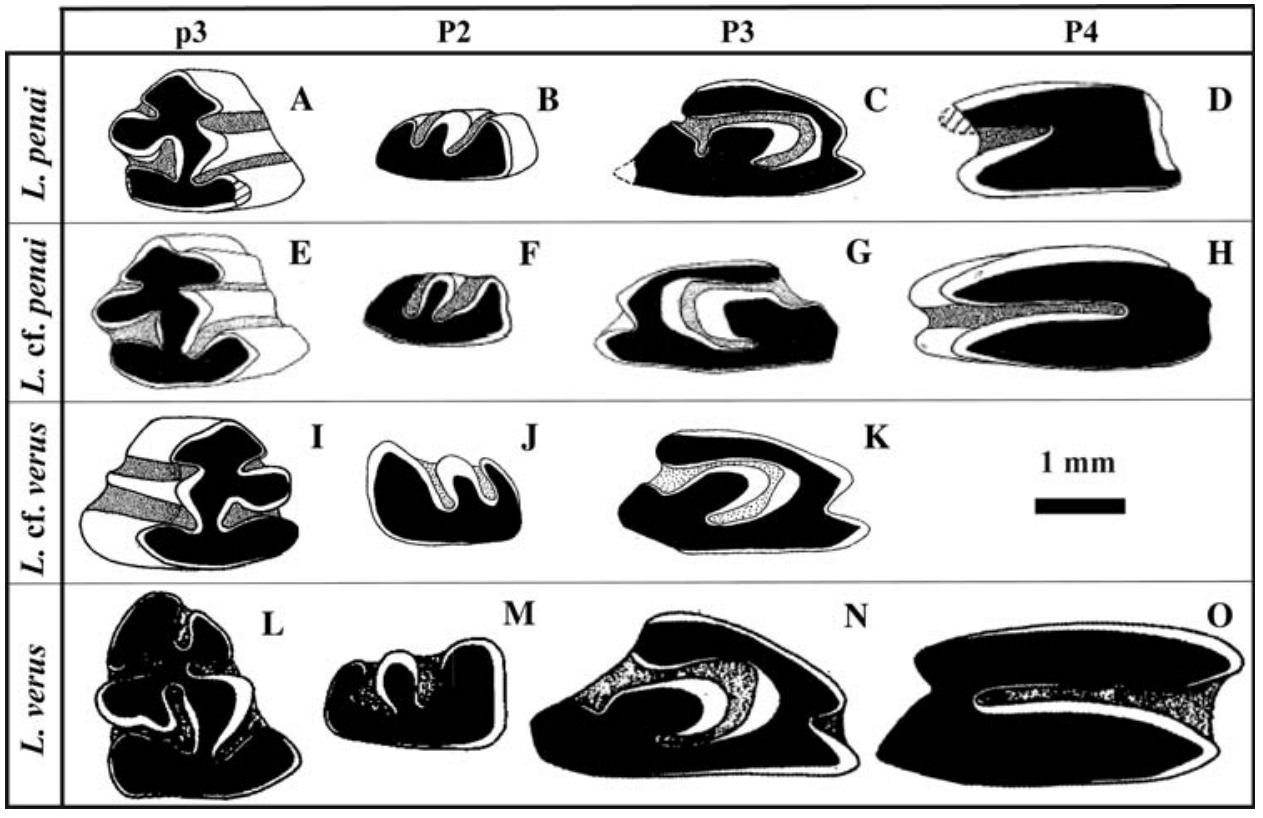




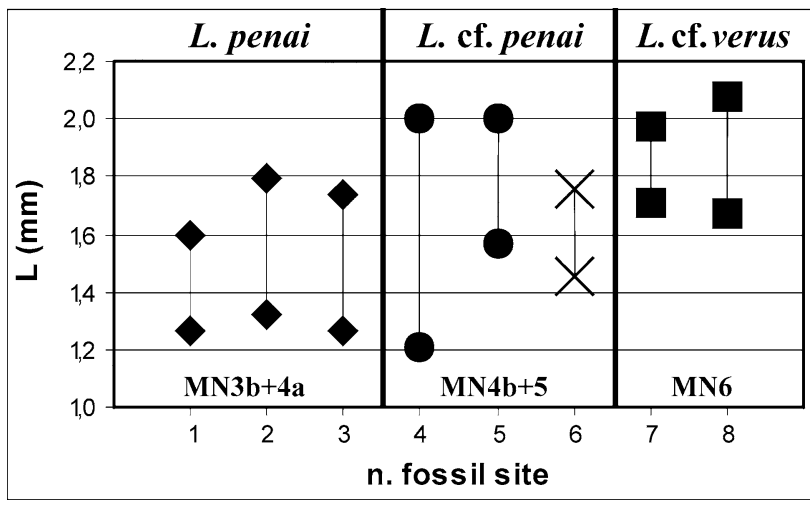

Fig. 4 Comparison of the observed range of the length $(L)$ of p3 of different populations of Lagopsis (Iberian Peninsula fossil sites; data from López Martínez 1984, 1989): 1 Ateca 3, 2 Villafeliche 2, 3 Buñol, 4 Rubielos de Mora 2, 5 Las Planas 4a, 6 Sandelzhausen, 7 Armantes 7,8 Manchones

relative abundance of Lagopsis to Prolagus is about $16 \%$, the climate should have been relatively cool and wet.

Genus "Amphilagus" Pomel, 1853

"Amphilagus" sp.

Fig. 5, Table 1

\section{Material}

p3 sin: 15909, 15911, 15912; p4 sin: 15903; m1 sin: ?15906, 15913; m2 sin: 15908; P2 sin: 15905; P3 sin: 15910; d2 sin: 15900.

\section{Description}

D2: very worn individual; relatively shallow and deep hypoflexus, only the parafossette is visible; two roots.

P2: the only available specimen is extremely worn; paraand mesoflexus very deep, parallel to the antero-posterior axis of the tooth and quite wide; postcone and lagicone of similar length, while the hypercone is slightly shorter; the size of the cusps decreases from postcone to hypercone.
P3: mesial hyperloph covering half of the triangular lagicone; mesial hyperloph separated from the main body of mesial hypercone by a notch; mesial hypercone slightly more pronounced than distal hypercone; C-shaped paraflexus, deeper than the mesoflexus; mesoflexus almost straight and parallel to the antero-posterior axis of the tooth; deep, V-shaped hypoflexus; bilobed postcone.

p3: globular trigonid and the talonid connected only by a central isthmus, or by a central isthmus plus a lingual one. In early stages of wear trigonid indented in its lingual side and connected by a lingual isthmus to the talonid; the talonid is connected by a central isthmus to a wide, flat hypoconulid, and the talonid has an anterior, central projection that possibly will become the central connection between trigonid and talonid observed in older individuals.

p4-m2: these three teeth have a lozenge-shaped trigonid and a roughly triangular talonid. In $\mathrm{p} 4$ the hypoconulid is large and connected to the talonid by a central isthmus. Hypoconulid absent in $\mathrm{m} 1$ and isolated but attached to the talonid in $\mathrm{m} 2$ (hypoconulid will be fused to the talonid in later stages of wear). A wear facet on the posterior wall of the only available $\mathrm{m} 2$ (evidence of the presence of a $\mathrm{m} 3$ ) seems absent.

"Amphilagus" sp. from Sandelzhausen is a primitive taxon, characterized by rooted teeth, a simple p3, and presence of a hypoconulid on the lower molarized teeth. In continental Europe, these characteristics are shared by the Oligo-Miocene genera "Amphilagus," Titanomys, and Eurolagus.

The Lower Miocene, small-sized species of the genus Titanomys have a somewhat more advanced lower tooth structure (hypoconulid present only on $\mathrm{m} 2$, p3 with more complex trigonid) than "Amphilagus" sp. (Fig. 6a).

Any affinity of "Amphilagus" sp. from Sandelzhausen with the genus Eurolagus can be excluded a priori, as the distribution of this monospecific genus is limited to MN7/8 and its migration route from Asia during MN7/8 can be traced from Anatolia to Europe (this means that Eurolagus

Fig. 5 "Amphilagus" sp.: a, b

left p3 15.911 and 15.912; c

right P2 15.905; d left P3

15.910; e-g left p4-m1-m2

$15.908,15.913,15.903$
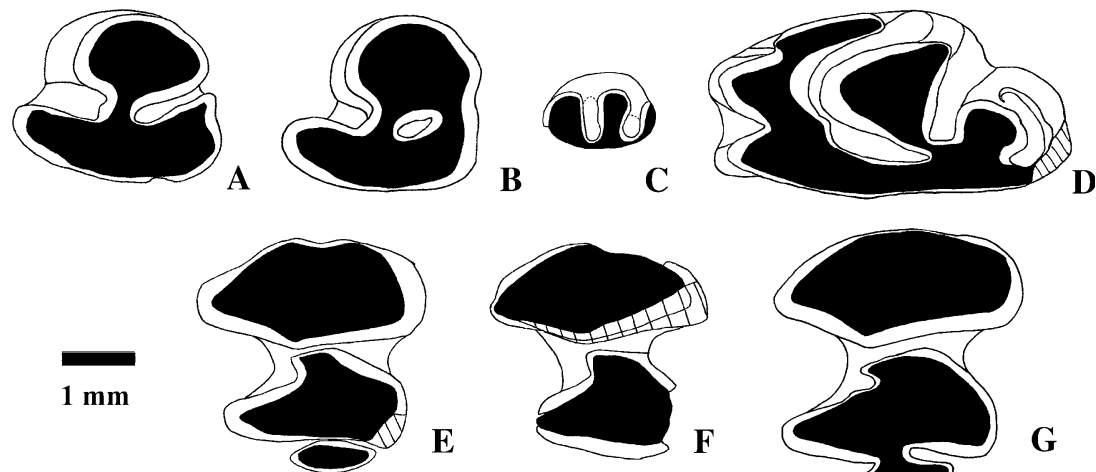

$\mathbf{E}$
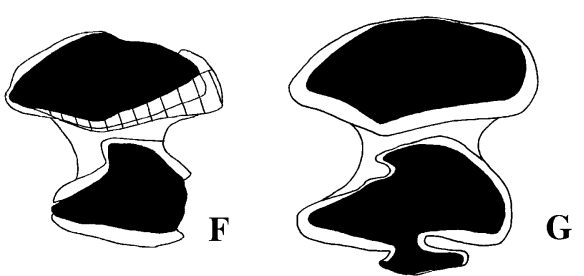
Fig. 6 Examples of dental morphologies of the three known genera of European primitive ochotonids. a, b, e left lower jaws (p3-m2); c, d left P3; f, g left p3 (from Tobien, 1974)

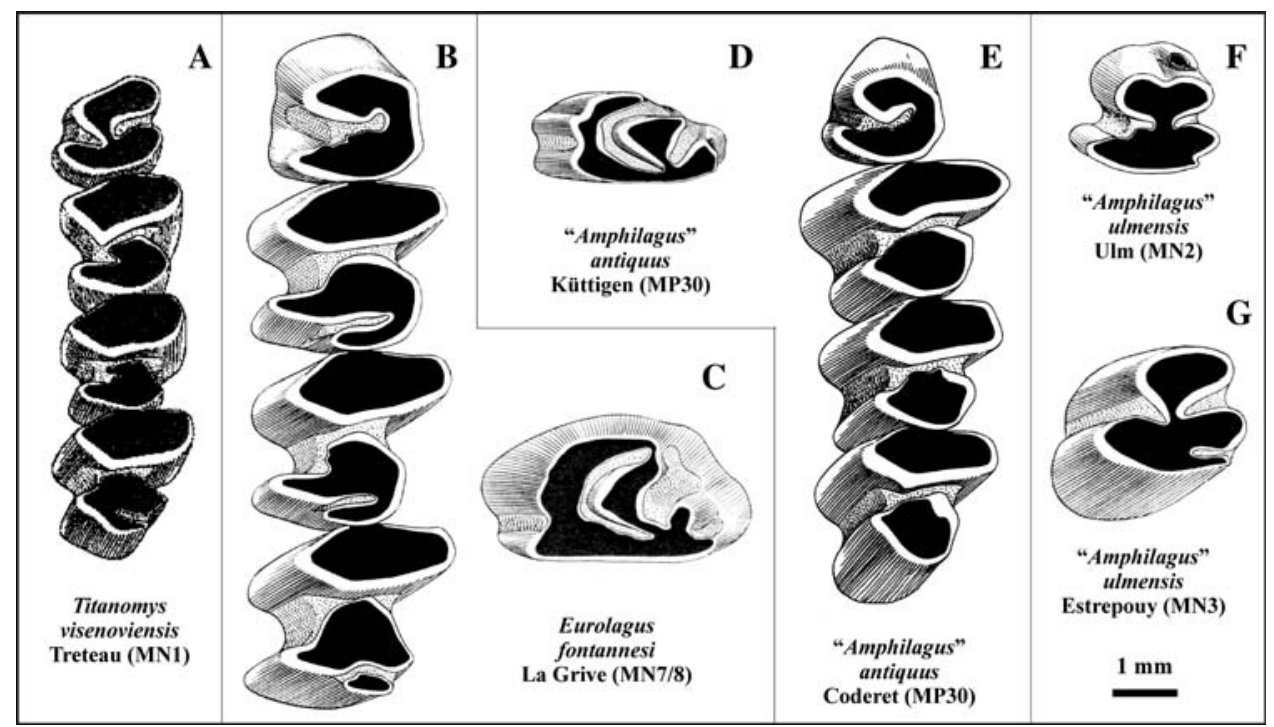

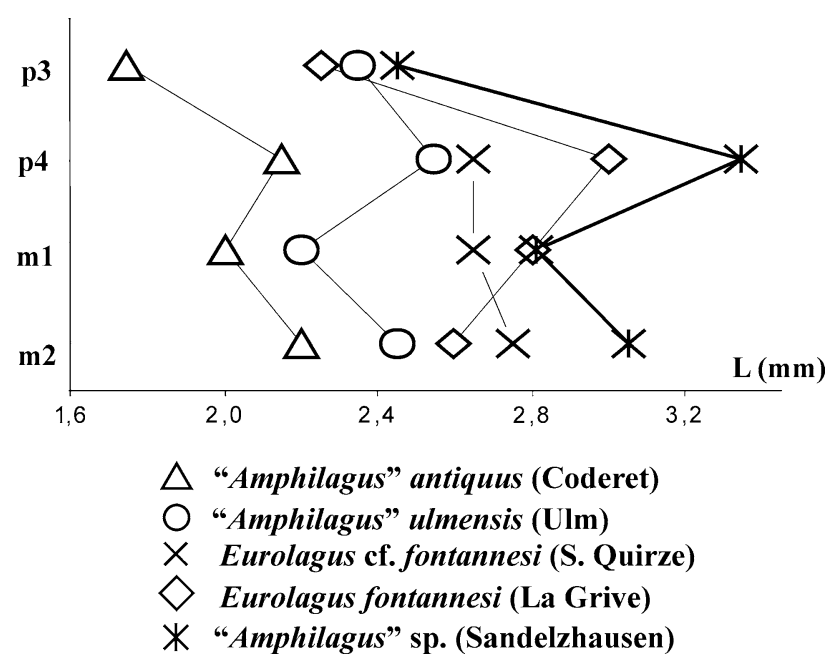

Fig. 7 Comparison of mean values of p3 length $(L)$ of some populations of European primitive lagomorphs (data from Tobien, 1974 and López Martínez 1989)

is an Asian immigrant and not a descendant of a European taxon; López Martínez 1989). To definitively exclude "Amphilagus" sp. from the origin of Eurolagus, it can be noted that the morphological and dimensional characters of "Amphilagus" sp. are derived compared with Eurolagus, and some morphological characters of the two genera are too different to hypothesize a close relationship between them (e.g., the connection of the hypoconulids in lower molariform teeth, central/lingual for "Amphilagus" sp., labial for Eurolagus; Fig. 6b). Other differences between "Amphilagus" sp. and Eurolagus are dental size ("Amphilagus" sp. from Sandelzhausen is the largest European primitive lagomorph currently known; Fig. 7) and P3 morphology (Eurolagus has a longer mesial hyperloph, shallower hypoflexus, small lagicone, and the mesial hypercone is much shorter than distal hypercone; Fig. 6c).

The Sandelzhausen rooted lagomorph shares only a few characters with "Amphilagus antiquus" (MP30). For example, the presence of $\mathrm{p} 3$ with a central or central + lingual trigonid-talonid connection, and $\mathrm{P} 3$ with a short mesial hyperloph and a large, triangular lagicone (Figs. 6d, e). Presence of these characters is not sufficient for a specific attribution to this taxon.

There are no common salient traits shared by " $\mathrm{Am}$ philagus" sp. from Sandelzhausen and the smaller "Amphilagus ulmensis" (MN1-5; Tobien 1974). The only similarity is the single central trigonid-talonid connection in p3, which is present in "Amphilagus ulmensis," but in "Amphilagus" sp. seems to appear only in an advanced stage of wear (Figs. 6f, g). Further, in-depth comparisons are problematic because different species, which are probably not directly related, have been included in " $\mathrm{Am}$ philagus ulmensis." The most important difference between the geologically oldest populations included in "Amphilagus ulmensis" and "Amphilagus" sp. from Sandelzhausen is that "Amphilagus" sp. lacks an anteroconid on p3. Comparing geologically younger populations of "Amphilagus ulmensis," the main difference from "Amphilagus" sp. is the presence in "Amphilagus ulmensis" of a very long, thin hypoconulid on $\mathrm{p} 3$ separated from the main body of the talonid by a deep lingual flexus. The hypoconulid is present in "Amphilagus" sp. only in early stages of wear, it is thicker, and is connected by a central isthmus to the talonid.

Until there is a general revision of the species included in the "waste-basket" genus "Amphilagus" (López Martínez 1977, 1989; López Martínez \& Thaler 1975), it is preferable not to further complicate European primitive 
lagomorph taxonomy and to classify the Sandelzhausen lagomorph provisionally as "Amphilagus" sp. Revision of the genus will clarify the spatial and temporal distribution of "Amphilagus" sp., in order to clarify its possible biochronological value, and to define its relationship with other European primitive lagomorphs. In particular it will be important to clarify if the appearance of "Amphilagus" sp. is due to local evolution or to migration from Asia, and to relate its appearance to palaeoecological/palaeoclimatic factors.

\section{Discussion and conclusions}

Analysis of the lagomorph component of the Sandelzhausen fossil site has demonstrated that:

- Three lagomorph genera are present: Prolagus, Lagopsis, and "Amphilagus".

- In some Prolagus teeth two morphological and size classes are present, one corresponding to $P$. oeningensis, the other resembling $P$. crusafonti. There are not sufficient data, however, to separate the Sandelzhausen Prolagus sample into two species. Thus it is preferable to classify all the Prolagus material as $P$. aff. oeningensis.

- A species of Lagopsis, whose morphological characters and size correspond to those of $L$. cf. penai, is present. This is compatible with a MN5 age. The relative abundance of Prolagus versus Lagopsis indicates relatively cool and wet climatic conditions.

- The Sandelzhausen rooted lagomorph, the largest-sized fossil lagomorph currently known in continental Europe, shows several affinities yet not a satisfactory resemblance to the Oligocene populations included in the "waste-basket" genus "Amphilagus," and it has been named provisionally "Amphilagus" sp.

In addition, this analysis has raised other larger-scale issues:

- systematic and palaeobiogeographic, including the possible presence of two different species of Prolagus at the Early/Middle Miocene boundary of central Europe

- taxonomic-nomenclatorial, as in the case of "Amphilagus" sp.

indicating the need for a general systematic revision of German lagomorphs, integrated with existing researches on the subject from western and southern Europe.
Acknowledgments I am grateful to Volker Fahlbusch and Gertrud Rössner for allowing me to study the Sandelzhausen lagomorph material, to the referees Margarita Erbajeva and Nieves López Martínez for their useful suggestions, and to Alisa Winkler for her careful review of the English language. Comparative analyses with the material from La Grive (NHM-Wien) and Escobosa (MNCNMadrid) were possible thanks to the kindness of Ursula Göhlich and Carmen Sesé. The Deutsche Forschungsgemeinschaft is acknowledged for providing funds to attend the Sandelzhausen Symposium 2005 in Mainburg (DFG GZ-4850/88/05).

\section{References}

Angelone, C. 2005. Systematic revision of genus Prolagus (Lagomorpha, Mammalia) in Italy and in western Mediterranean islands: new systematic tools, biochronology and palaeogeography. Unpublished Ph.D. Thesis, Università Roma Tre, 135 pp.

Angelone, C., and C. Sesé. 2009. New characters for species discrimination within the genus Prolagus (Ochotonidae, Lagomorpha, Mammalia). Journal of Palaeontology 83(1): 80-88.

Fahlbusch, V., H. Gall, and N. Schmidt-Kittler. 1974. Die obermiozäne Fossil-Lagerstätte Sandelzhausen. 10. Die Grabungen 1970-1973 Beiträge zur Sedimentologie und Fauna. Mitteilungen der Bayerischen Staatssammlung für Paläontologie und historische Geologie 14: 103-128.

López Martínez, N. 1974. Evolution de la lignée d'Ochotonidés Piezodus-Prolagus dans le Cénozoïque d'Europe Sud-Occidentale. Unpublished Ph.D. Thesis, Université des Sciences et Techniques du Languedoc, Académie Montpellier, 165 pp.

López Martínez, N. 1977. Nuevos lagomorfos (Mammalia) del Neogéno y Cuaternario español. Trabajos Neogeno/Quaternario 8: 7-19.

López Martínez, N. 1984. Los Lagomorfos (Mammalia) de la sucesión del Mioceno inferior de Calamocha (prov. de Teruel). Colóquios de Paleontología 39: 27-44.

López Martínez, N. 1989. Revisión sistemática y biostratigráfica de los Lagomorpha (Mammalia) del Terciario y Cuaternario de España. Memorias del Museo Paleontológico de la Universidad de Zaragoza 3: 1-342.

López Martínez, N. 2001. Palaeobiogeographical history of Prolagus, an European ochotonid (Lagomorpha). Lynx (n. s.) 32: 215-231.

López Martínez, N., and L. Thaler. 1975. Biogéographie, évolution et compléments à la systématique du groupe d'Ochotonides Piezodus-Prolagus (Mammalia, Lagomorpha). Bulletin de la Société géologique de France 17: 850-866.

Moser, M., G.E. Rössner, U.B. Göhlich, M. Böhme, and V. Fahlbusch. 2009, this volume. The fossil lagerstätte Sandelzhausen (Miocene; southern Germany): history of investigation, geology, fauna and age. In: Rössner, G.E., Göhlich, U.B. (Eds) Fossil lagerstätte Sandelzhausen (Miocene, southern Germany): Contributions to the fauna. Paläontologische Zeitschrift 83(1):000-000.

Tobien, H. 1974. Zur gebißstruktur, Systematik und Evolution der Genera Amphilagus und Titanomys (Lagomorpha, Mammalia) aus einingen Vorkommen im jüngeren Tertiär Mittel- und Westeuropas. Mainzer geowissenschaftliche Mitteilungen 103: $103-186$. 